\title{
Urban sprawl functional-structural changes in neighborhood settlements: Case of study Shiraz
}

\author{
Musa Kamanrudi Kojuri ${ }^{1)}$, Kamran Jafrpour Ghalehteimouri' ${ }^{2}$, Ali Janbazi ${ }^{1)}$ and Farhad Azizpour ${ }^{1)}$ \\ ${ }^{1}$ Urban Planning and Geography, Faculty of Geography Sciences, Kharazmi University of Tehran. 43 South Mofatteh \\ Avene, Tehran, 15719-1491, Iran.
}

${ }^{2}$ DPPC-MJIIT-UTM

Received: 2019-11-23 Accepted: 2020-05-05

Keywords:

Shiraz; Urban Expansion;

Sprawl; Urban Sprawl; Structural

and Functional Changes

Correspondent email: Kamanroodi@khu.ac.ir

\begin{abstract}
Sprawl is one of the forms of expansion that has entered the literature of urban management and planning in the last half-century. Iranian cities are very good example for city sprawl and they have experienced this kind of expansion in very short period and very fast. This paper aims to identify, describe, and analyze Shiraz scatter and sprawl development and its resulting functional-structure, this research is based on exploratory, descriptive and analytical methods. Data collection in this research is through the secondary data and fieldwork research techniques. Data analysis demands descriptive and inferential statistics (Pearson regression correlation). This study suggests that since 1952 Shiraz city has experienced rapid growth, continuous and non-continuous. The proportion of scatter and sprawl development with respect to Shiraz expansion increased from 22.02 in 1957-1967 to 72.8 in 1977-2007. There are three period the first rapid development between 1957 and 2967 after that 5 years gap and the next period which is longer from 30 years between 1977 and 2007. This turning points is in two specific periods are as the result of some consequences: Conversion of agricultural function as a predominant economic function in neighboring communities, into multi-functional agricultural function with emphasis upon services; of some of the rural settlements into Shiraz; The development of extended spatial, administrative, economic, social and structural changes in residential part of Shiraz. Therefore, socioeconomic activities are the main cause of urban sprawl in Shiraz and made Shiraz the most attractive place for in Fars Province. Population growth with correlation between degree of Shiraz scatter development and number of people engaged to service sector by 0.9 has caused a dramatically decline in agriculture $(-0.8)$ and industry $(-0.811)$ sectors. As result rapid urban population growth rate correlation by $(0.127)$ and urbanization coefficient $(0.726)$ and it shows urban and rural migration very important role on scatter development.
\end{abstract}

2020 by the authors. Licensee Indonesian Journal of Geography, Indonesia.

This article is an open access article distributed under the terms and conditions of the Creative Commons

Attribution(CC BY NC) licensehttps://creativecommons.org/licenses/by-nc/4.0\%.

\section{Introduction}

The growth foundation of developing countries generally based on modernization theory, industrial growth approach, and growth pole strategy in 1950-60 in Iran was not an exception in this regard. The Neoclassical Growth Theory developed to improve the bottom-up decision-making in the planning system and for empowering the local governments. This theory started with James E. Meade, 1951 and then was further developed in the works of Robert M. Solow, 1956 and Trevor Swan, 1956 (Komarovskiy and Bondaruk, 2013). In the 20th century, it started to happen in Iran. However, it was accelerated since 1957 specifically, growth pole strategy was considered to be a national, regional planning base between1969-78 namely under Iran forth a development plan (1969-1973). Yet, it is known as one of the most effective tools to integrate urban and rural disparities (Fen et al., 2020) somehow linking urban-national-international interests to attract more money in megaregions can reduce or increase the neighboring urban regions activities (Zhao et al., 2020; Bogart, 2006) and changing the meaning of the place by new industrial or recreational use of lands (Movahed \& Jafarpour Ghalehteimouri, 2019), and leave a negative impact on the other regions. These kinds of development orientations, plans, and measures resulted in the concentration of resources and infrastructures in growth centers. As a result, this theory of planning caused development gaps, migration, and scatter and sprawl development, and extended structural -functional changes including land-use changes in neighboring communities. After that, there is a dramatic sectoral shift in growth centers, city function changed as well, and many people from agricultural sectors moved to the industrial sector or service. Therefore, Shiraz as one of the main growth poles which are located in the Zagros region with a very big influence on other small cities and villages become an attractive center for areas that were under the Shiraz region influence. Since 1952, Shiraz has experienced continuous and non-continuous growth pattern along major roads. This growth based on service and industrial oriented activities.

This study aims to investigate type, direction, rate and the causes of the Shiraz historical expansion. It further tries to find out its political, economic, physical, and social impacts upon neighboring communities' between1957-2007. More specifically the major objectives is to identify, describe, and 


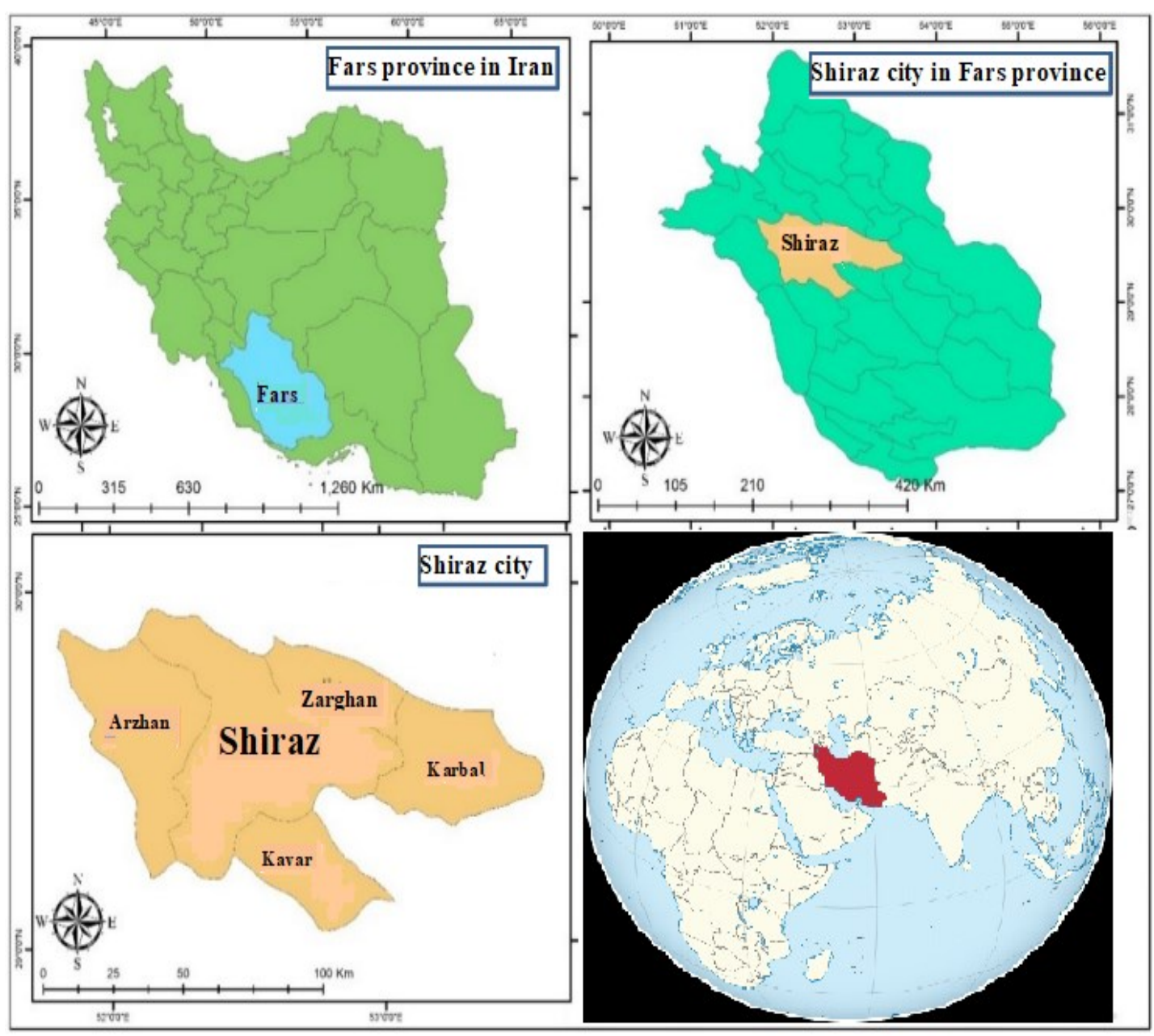

Figure 1. Location of Shiraz Province in Iran

analyze the trend of functional, structural changes happened in Shiraz neighboring settlements within the period of study.

Modernization theory deals with the analysis of complex sets of spatial, political, economic, social, cultural, and psychological changes and transformations associated with the transition from agrarian traditional societies to industrial modern ones. This theory depends on both evolutionism and functionalism in order to describe the new modern nature of third world countries. Evolutionism believes that modernism is an evolutionary and gradual change rather being considered as a revolutionary change. Based on functionalism approach, modernism represents a systematic, internal, and transformative process. In very short, the urban expansion in developing countries is a socio-economic evolution and cause a structural transformation with new sectoral development. The economy is being considered as one of the theoretical and applied domains of modernism. Economic modernization pattern exemplified itself in the modernization of industries, technology, agriculture, services as well as the change in labor force. The proponents of economic modernism believe that industrial modernism requires the introduction of new types of machinery as well as new ways of production techniques. Rostow (1955) classified the development trend of the countries into five stages including traditional, transitional, take off, maturity and mass consumption (Rush, 1999).

Polarized development strategy as a welcomed one with its associated industrial growth and efficiency is very much aligned with modernism and industrial growth approach.

François Perroux put forwarded growth pole as a spatial strategy in 1955 to prevent concentration of Paris. He believed that scattering activities over space and anti-concentration measures could well dissipate development all over. This could have both some positive and negative feedbacks and consequences. Economic dynamics and their impacts on settlements growth and development are among the positive results. However, this may lead to some negative outcomes including migration, unemployment, inappropriate age and sex structure and unorganized and remote services location (Saeedi, 2013:155). This approach as a policy tool received some attention regarding spatial regional planning in different countries, including Iran in the 1960 decade. This was facilitated by the government financial support the source of finance was from the oil money and injected to the national economy. The oil money not only reduced the government dependency to agriculture in rural areas also the government needed more people in urban areas for industrial development (Soleimani et al., 2013). Furthermore, it was associated with industrial workforces, unprecedented rural-urban migration that encouraged people to migrate to cities for better life and more money. Cities have never welcomed new comers and this rapid and unblessed migration caused physical urban expansion into peripheries.

American cities have rapidly expanded outward since the 1950 decade. This was associated with swallowing lots of agricultural lands and forested areas. In addition, it has led to some negative environmental impacts and greater traffic problems (Bhatta, 2010:7). Scatter development and urban sprawl correspond to uncontrolled urban growth and 


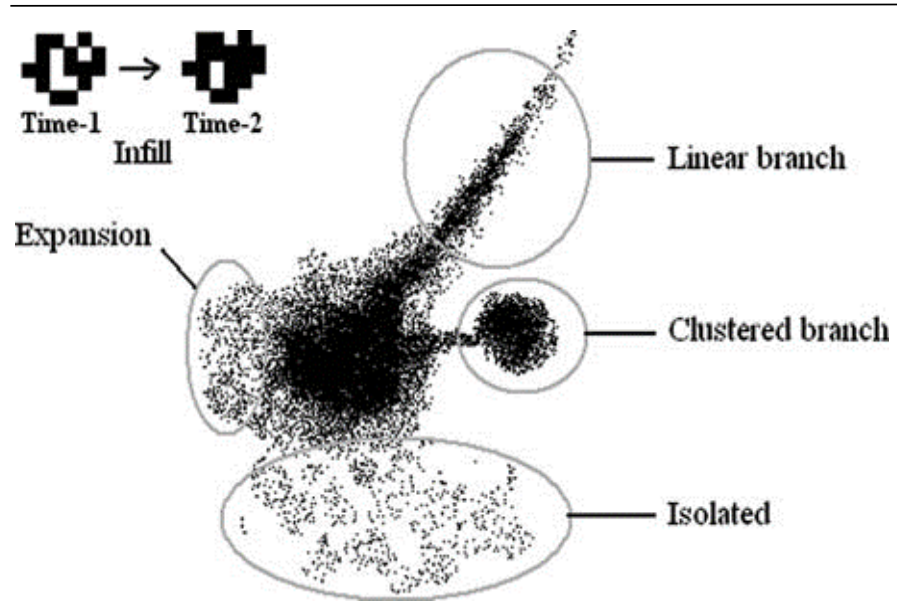

Figure 2. Schematic diagram of urban growth pattern Source: Bhatta, 2010: 11

expansion, (Zhang, 2004) and high reliance on private cars and the development of highways (Hess, 2001). Land price encouraged the newcomers to choose urban fringes (Mendonça et al., 2020) urban sprawl and changes in urban fringes in different land covers show different occupation status (Hussein et al., 2013). Air pollution and polluted industrial development can contribute to the regional and national air pollution levels (Feng \& Wang, 2020; Kiggundu, 2014; Giyarsih, 2017). These phenomena were associated with the greatest amount of housing construction activities after The Second World War (Duany et.al, 2001). The complexity and magnitude of the resulting changes were the direct outcomes of government executive intervention at all levels (Gutfreund, 2004: 231).

Urban growth, urban expansion, urban sprawl, and urban development even though have something in common, but they are different. Urban growth is a general concept that represents the degree of urban occupied lands. However, urban expansion is associated with the degree, direction (Horizontal, vertical) and a form of urban growth. Urban sprawl as one form of urban expansion generally bears negative meaning. Urban development corresponds to the improvement of some aspect of our life. The national policies and ideology on land and natural resources can changes the meaning of land-use by liberation of the use of land (Kovács et al., 2019) as it happened in former socialist countries.

(Wilson et al., 2003) identified three types of urban growth, including infill, expansive, and outlying. Horizontal expansion away from the city centre will lead to isolated, linear, and cluster growth pattern (Bhatta, 2010: 10) (Figure 2).

Urban sprawl indicates over-consumption of lands, nonstop and continuous horizontal expansion, leapfrogging growth as well as inefficient land utilization (Peiser, 2006). According to the Vermont Association, this phenomenon has both urban and rural characters happened along roads and highways in rural suburbs (Frumkin, 2004:1). It is argued that sprawl is associated with plan free development taking place in peripheries along major routes in haphazard and peace meal fashion (Rahman et.al, 2008). Urban sprawl represents development over isolated areas separated by vacant lands (Ottensmann, 1977). This is known as a leapfrogging growth (Gordon \& Richardson, 197). Urban sprawl is known three major urban spatial dynamics that are known as: the CBD overdevelopment and over concentration; unplanned development in urban edge as result of the CBD functions; and rapid urbanization with more influence on further lands with cities - core and edge functions (Nengroo et al., 2017).

Some of the scholars treat urban sprawl like cancer (Dilorenzo, 2000). However, the phenomena are considered as an urban settlement over the rural landscape (Harvey, 1965), low-density urbanization (Pendall, 1999), consumption of peripheral lands (Wilson et.al, 2003) and non-continuous development (Weitz \& Moore, 1998). In the global south unplanned-urban development in different level and size of cities become a norm where there is lack of link between different scales and sectors in urban planning hierarchy (Soria et al., 2020). According to environmental protection agencies, sprawl at a metropolitan scale occurs when the rate of land conversion to non-agricultural use exceed over population growth rate (Barnes et.al, 2001). Hanson believes that there exists no common agreement regarding these phenomena (Johnson, 2001). Barnes and others stated that the definition of these phenomena is dependent upon the applied ideology and structural contexts (Barnes et.al, 2001). When the national polices and ideology on urban planning and policies does not support appropriate solutions and there are not appropriate infrastructure to support smart growth and sustainable urban regeneration (Paydar \& Rahimi, 2018) the problems remain and in terms of the time it become dilemma for different level of decision making. Galster and others criticized the existed contextual bias regarding sprawl development. They believe that these phenomena could be parallel to the special pattern of land utilization, land development process, special land treatment and its consequences (Galster et.al, 2001). He believes that urban sprawl could be investigated by density, continuity, concentration, clustering, centrality, central dependency, mixed land uses, and contingency (Glaeser, 2004). Rapid urban expansion and population growth (Nedaetousi, \& Bagheri, 2017) in cities surrounded by agricultural land can reduce economic role of city and destroy urban environment (Ahadnejad Reveshty et al., 2019) Ewing and others believe in density, mixed land uses centrality and accessibility as major elements for investigation of this phenomenon (Ewinget al., 2002). Burchell and others stated that unlimited expansion regarding undeveloped areas, low density, and non continuous expansion are the prime specifications of scatter and sprawl development (Burchell et al, 2005: 21). Based on above remarks and definitions low density, step, scattered and leapfrogging development as well as separation of land uses is being considered as the major characteristics of this phenomena. However, one could argue that out of those characteristics densities as a ratio between occupied lands for construction and population growth rate would be considered as the most common indicators with respect to urban sprawl (Hydari \& Soleimani, 2013:15). These phenomena regardless of its causes could be considered as a low-density growth and expansion initiated from compact urban nodes which experiencing many environmental push factors. This could have a great impact on the sustainability issue and residents living conditions.

To describe the preceding definition, non-sprawling development means: (1) discouraging outgrowth; (2) in case of any unavoidable outgrowth, it should be highly compact to reduce the city-size; (3) urban growth-rate should not exceed 
the population growth rate of that area; and (4) should not harm the interest and need of human and environment much, in the context of present and future. Fulfilment of these expectations tends to a smart and sustainable urban growth, failing of which results in sprawl (Bhatta, 2010: 9).

According to some scholars, urban sprawl is neither black nor white. They believe that urban sprawl has some positive impacts, including access to more economic productions, provision of job opportunities and achieving a better lifestyle due to getting the advantage of different opportunities (Meshkini \& Parhiz, 2011:169). They argue that care for citizen's privacy and provision of space in which millions of citizens could have private dwellings in a secure and pleasant environment are among some of the urban sprawl advantages in the United States (Williamson, 2010:17). However, low density could not be considered as a prime indicator of urban sprawl. It is argued that density was associated with the urban history of America, Europe, as well as Mesopotamia. Thus, it does not just pertaining to the twentieth century. (Bruegmann, 2006:17-18).

\section{The Methods}

This research based on its objectives is considered to have theoretical nature. However, taking into consideration its nature as well as its method, it has exploratory, descriptive, and analytical character. Its theoretical approach is based on functional, structural one. Its statistical society corresponds with the residential area of Shiraz. Data collection has done via documentary and fieldwork technique. Data analysis, demand application of GIS in order to analyze the rate, direction, and form of Shiraz urban sprawl development between 1957-2007. This is further followed by application of Holden model regarding computation of degree of sprawl development in Shiraz. The variables of this study include physical, economic, social and political characteristics with 23 corresponding indicators (Table 1).

\section{Result and Discussion}

Both population and sectoral development have been a missing point in previous studies. Since the growth foundation of developing countries generally based on modernization theory, shifting from an agricultural and an industrial-based society to rapid increase in the service sector has changed socioeconomic activities in the metropolitan areas. Therefore, urban population growth and migration rate are higher than any other place in the metropolitan area and if in 1950-1960 industrial growth approaches and growth pole strategies under the modernization theory have been the engine of development, service sector growth has changed the shape and rate of the previous development theories.

Based on table 2 and figure 5, Shiraz experienced a population growth rate of 1.68 and 7.19 percent in 1957 and 1987 respectively. Physical expansion of the city indicates almost the same degree of growth. However, the year 1979 was associated with a decrease in both population growth rate and horizontal expansion. Thus, 1957 and 1997 considered an important breakthrough regarding both population growth rate and horizontal expansion. This city

Table 1. Variables and research indices

\begin{tabular}{ll}
\hline Variables & Indices \\
\hline Political sub division & Number of counties, district, town, villages, cities \\
Economy & $\begin{array}{l}\text { Occupational structure, occupational ratio, number of employees, ratio of employees, predominant } \\
\text { economic function }\end{array}$ \\
$\begin{array}{l}\text { Demographic Compo- } \\
\text { sition }\end{array}$ & $\begin{array}{l}\text { Number of population growth rate, sex ratio, number of household, size of household, urbanization } \\
\text { coefficient } \\
\text { Spatial Expansion }\end{array}$ \\
$\begin{array}{l}\text { Area, growth per capita, degree of expansion, direction of expansion, pattern of expansion, form of } \\
\text { expansion, percentage of scatter and sprawl development }\end{array}$ \\
\hline
\end{tabular}

Table 2. Changes associated with number of population, area, and scatter sprawl development in Shiraz

\begin{tabular}{llllllll}
\hline Year & $\begin{array}{l}\text { Number of } \\
\text { population }\end{array}$ & $\begin{array}{l}\text { Percentage of } \\
\text { population } \\
\text { growth }\end{array}$ & $\begin{array}{l}\text { Area in } \\
\text { Acres }\end{array}$ & $\begin{array}{l}\text { Per capita } \\
\text { of area } \\
\left(\mathrm{m}^{2}\right)\end{array}$ & $\begin{array}{l}\text { Degree of } \\
\text { increase }\end{array}$ & $\begin{array}{l}\text { Percentage of development } \\
\text { associated with population } \\
\text { growth }\end{array}$ & $\begin{array}{l}\text { Percentage of } \\
\text { scatter and } \\
\text { sprawl }\end{array}$ \\
\hline 1927 & 101974 & - & 447 & 52,39 & & & \\
1957 & 170659 & 1,68 & 894 & 59,62 & 2 & 77.98 & 22.02 \\
1967 & 269865 & 4,69 & 1609 & 83,14 & 1.8 & 57.84 & 42.16 \\
1977 & 425813 & 4,67 & 3540 & 154,40 & 2.2 & 52.68 & 47.32 \\
1987 & 848289 & 7,14 & 13098 & 190,91 & 3.7 & 50.47 & 49.53 \\
1997 & 1053025 & 2,19 & 20103 & 279,88 & 1.5 & 27.20 & 72.80 \\
2007 & 1214808 & 1,44 & 34000 & 52,39 & 1.69 & \\
\hline
\end{tabular}

Source: Bureau of Iranian Statistics 1957 to 2007 


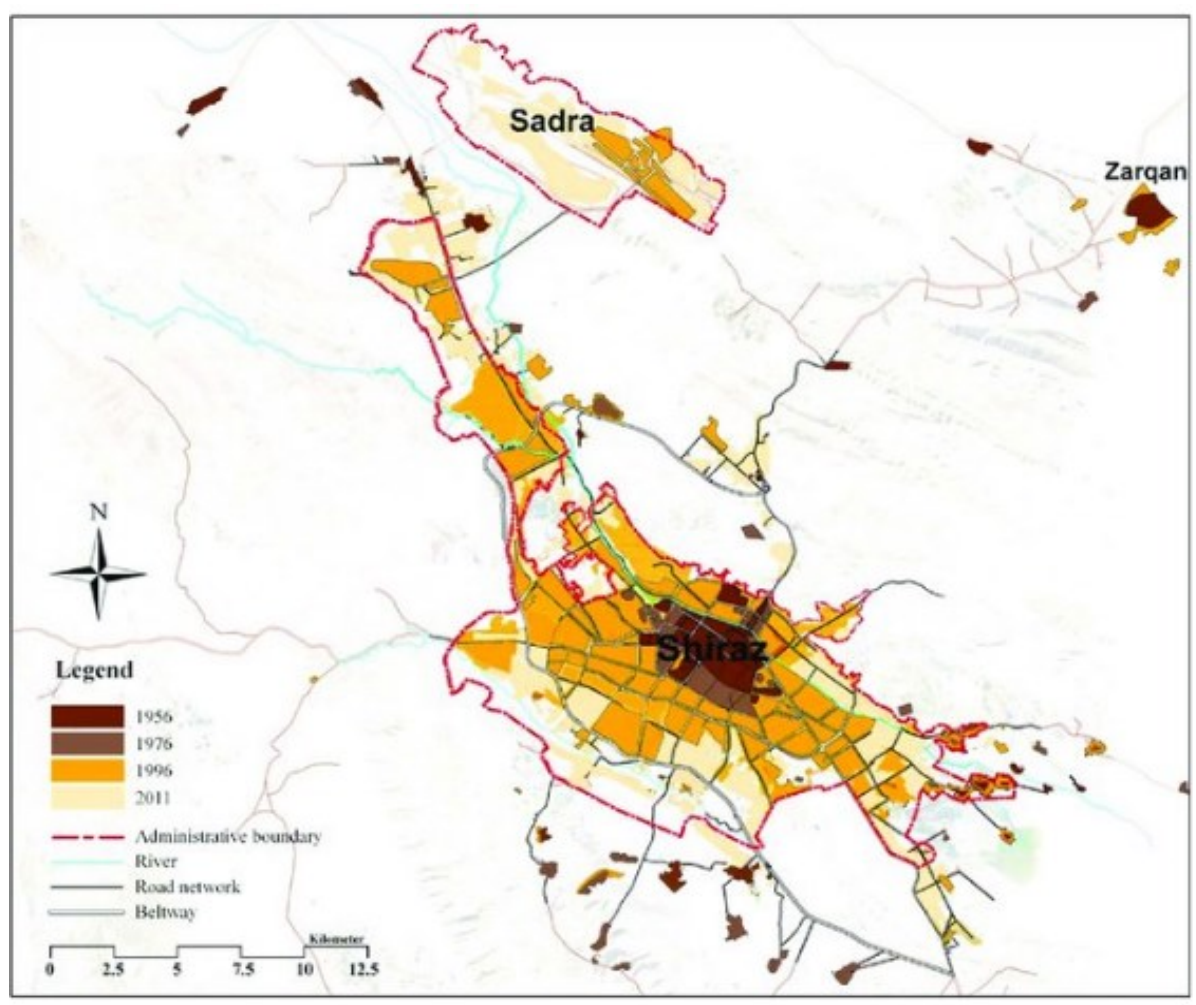

Figure 4: Shiraz Expansion up to 2001

experienced the highest population growth rate as well as physical expansion between1977-87. Shiraz population doubled due to its growth rate $(7.15$ percent). Its area increased 3.7 fold in the decade. However, population growth rate pertaining to $1987-97$ said to be 2.9 percent. That means 4.95 percent decrease compared to last decade. Its area increased 1.5 fold. This growth and expansion were associated with urban sprawl as well as annexation and merging of neighbouring communities. Population growth rate within 1997-07 was 1.44 percent, which was lower than the previous decade. However, its area experienced 1.69-fold increase because of merging and annexation of neighbouring communities.

Shiraz has expanded and extended along major roads and arteries both in continuous and non-continuous fashion within the different periods of the time and this expansion taking into consideration the topographic configuration. These axes and their margins act as a sprawling domain capable of handling population overflow. These areas are associated with industries, warehouses, military centres and residential towns. Based on the Holden model, 54 percent of Shiraz horizontal expansion between 1957-07 is associated with population growth and 46 percent is the result of scattering and sprawl development. Census corresponding to 1957 and 2007 suggests that population growth rate plummeted from 77.98 in 1957-67 to 27.2 in 1997-07. However, sprawl share increased from 22.2 (1957-67) to 72.8 (1997-07) (table 2 and figure 4).

\section{Political Administrative Changes}

Sprawl development and expansion into neighbouring communities between 1957-07 has led to new administrative political subdivisions. A first subdivision which resulted in recognition of Shiraz, Marvdasht, and Sepeedan happened between1967-77. Shiraz was divided into five districts. Associated villages changed from 9 to 21 between1988-91. Moreover, the new village named Derug was founded as well and Arjang district with its three villages was separated from

Table 3. Shiraz metropolitan sub-division (from 1957 to 2012)

\begin{tabular}{ccccc}
\hline Year & Number of District & Number of town & Number of cities & Number of villages \\
\hline 1957 & - & - & - & - \\
1967 & - & - & - & - \\
1977 & - & - & - & - \\
1987 & 4 & 9 & 5 & 689 \\
1997 & 6 & 22 & 5 & 819 \\
2007 & 6 & 22 & 7 & 619 \\
2012 & 3 & 12 & 10 & 487 \\
\hline
\end{tabular}

Source: Bureau of Iranian Statistics 1957 to 2012 
Shiraz the same period of time. No changes in terms of political-administrative subdivisions occurred between 199707. However, this urban area was divided into four cities, Shiraz, Sarvestan, Koar and kharme between2007-2011. However, the number of villages was plummeted from 22 to 12. 1997-2007 experienced the addition of two more cities, Darian and Lupoyee. Shiraz now with the addition of five more new towns is composed of nine towns, Shiraz ,Sadraei,Zarghan, Lupoyee ,Bande Amir , Rahmatabad ,Khanezinan and Arjang plain (table 3).

\section{Social and demographic changes}

The Shiraz metropolitan population increased from 437760 in 1967 to 1675873 in 2007 . Its population growth rate was 3.41 percent within this period of time that is lower than the Shiraz population growth rate (4.03) and higher than the province rate (2.8). These high rates of growth are associated with a high level of migration. Shiraz metropolitan, as well as Shiraz and Fars provincial, experienced high population growth rate up to 1977. However, population birth control policy along with the counter stream of war migrants toward their hometowns resulted in a decrease in population growth rate. Shiraz low population growth rate compared with Shiraz metropolitan rate between 1997-07 proved scattered, sprawl pattern of growth in former. As such the ratio of Shiraz population to Shiraz metropolitan and Fars province which was 61 and 18 percent respectively reached to 75.78 and 27.59 percent (table 4)

The Shiraz metropolitan urbanization coefficient indicates an increase between 1967-77. However, it shows a decrease in 2007. The coefficient pertaining to 1967 was 37.98. This reached 80.68 in1997. However, it dropped in 2007 (78) (table 5). Iran's urbanization coefficient and Fars province increased as well. However, this rate compared to Shiraz metropolitan was lower. One could conclude that an increase in urbanization coefficient of Shiraz metropolitan between1967-97 and its magnitude compared to Iran's and Fars province as well as the decrease in its rural population all are associated with scattering and sprawl growth pattern and functional Changes of neighboring communities.

\section{Economic changes}

There exist a drastic decrease in the percentage of the population engaged in agriculture in Shiraz and Shiraz metropolitan in 1957 as opposed to 2007. The associated figures for Shiraz metropolitan, Shiraz and rural settlements were 43.8, 9.85, 6.4, 3.16, and 70.1 and 32.54 percent respectively. However, the percentage of the population engaged in agriculture in Shiraz in 1987 and 1997 compared to previous the periods showed some increases (table 6). This corresponds to a decrease in population engaged in the industrial sector. This would well-justified consideration of Shiraz as one of the Iranian development poles. Many industries including petrochemical, sugar, food processing, packaging, wood products, textile, electric, chemical, construction and handicrafts industries are all located in Shiraz.

The percentage of people engaged in the industrial sector compared with the total engaged in Shiraz metropolitan increased between1957-97. However, the percentage of the industrial labor force associated with Shiraz decreased between 1957-07. Moreover, people engaged in the Shiraz metropolitan industrial sector, percentage-wise increased in 1997. However, one could see a remarkable decrease in 2007. This figure shows little increase in Shiraz in 2007 compared

Table 4. Population, growth rate and sex ration associated with Shiraz metropolitan and province

\begin{tabular}{cccccccccc}
\hline & \multicolumn{3}{c}{ Shiraz } & \multicolumn{4}{c}{ Shiraz Metropolitan } & \multicolumn{3}{c}{ Fars Province } \\
\cline { 2 - 11 } Year & $\begin{array}{c}\text { Number of } \\
\text { population }\end{array}$ & $\begin{array}{c}\text { Growth } \\
\text { rate }\end{array}$ & $\begin{array}{c}\text { Sex } \\
\text { ratio }\end{array}$ & $\begin{array}{c}\text { Number of } \\
\text { population }\end{array}$ & $\begin{array}{c}\text { Growth } \\
\text { rate }\end{array}$ & Sex ratio & $\begin{array}{c}\text { Number of } \\
\text { population }\end{array}$ & $\begin{array}{c}\text { Growth } \\
\text { rate }\end{array}$ & Sex ratio \\
1967 & 269,865 & - & 112.5 & 437,760 & - & 109.43 & 1493804 & - & 107.51 \\
1977 & 425,813 & 4.67 & 115 & 640,495 & 3.88 & 112.4 & 2035582 & 3.52 & 105.75 \\
1987 & 848,289 & 7.14 & 105 & $1,125,405$ & 5.8 & 105.08 & 3193769 & 4.61 & 104.89 \\
1997 & $1,053,025$ & 2.19 & 105.8 & $1,389,628$ & 2.13 & 106.7 & 3817036 & 1.8 & 103.43 \\
2007 & $1,214,808$ & 1.44 & 103 & $1,675,873$ & 1.89 & 105.3 & 4336878 & 1.28 & 103.42 \\
\hline
\end{tabular}

Source: Bureau of Iranian Statistics 1967-2007

Table 5. Urbanization coefficient associated with Iran Fars Province, Shiraz Metropolitan

\begin{tabular}{cccccc}
\hline $\begin{array}{c}\text { Urbanization coefficients } \\
\text { Statistical society }\end{array}$ & 1967 & 1977 & 1987 & 1997 & 2007 \\
\hline Iran & 37.98 & 47.03 & 54.29 & 61.31 & 68.46 \\
Fars Province & 40.34 & 42.88 & 50.87 & 56.67 & 61.17 \\
Shiraz Metropolitan & 66.37 & 70.64 & 79.69 & 80.68 & 78 \\
\hline
\end{tabular}

Source: Bureau of Iranian Statistics 1967 to 2007 
Table 6. Occupational distribution in Shiraz, Shiraz Metropolitan, and Shiraz communities

\begin{tabular}{cccccccccc}
\hline \multirow{2}{*}{ Year } & \multicolumn{3}{c}{ Shiraz Metropolitan } & \multicolumn{3}{c}{ Shiraz } & \multicolumn{3}{c}{ Shiraz rural communities } \\
\cline { 2 - 9 } & $\begin{array}{c}\text { Agricul- } \\
\text { ture }\end{array}$ & Industry & $\begin{array}{c}\text { Ser- } \\
\text { vices }\end{array}$ & $\begin{array}{c}\text { Agricul- } \\
\text { ture }\end{array}$ & $\begin{array}{c}\text { Indus- } \\
\text { try }\end{array}$ & $\begin{array}{c}\text { Ser- } \\
\text { vices }\end{array}$ & $\begin{array}{c}\text { Agricul- } \\
\text { ture }\end{array}$ & $\begin{array}{c}\text { Indus- } \\
\text { try }\end{array}$ & $\begin{array}{c}\text { Ser- } \\
\text { vices }\end{array}$ \\
\hline 1957 & 43.7 & 24 & 32.3 & 6.4 & 33.1 & 60.5 & 70.1 & 17.8 & 12.4 \\
1967 & 31.7 & 28.1 & 36.2 & 4.98 & 32.39 & 62.63 & 66.4 & 22.3 & 11.3 \\
1977 & 17.69 & 28.98 & 53.33 & 2.71 & 27.18 & 70.1 & 54.58 & 32.65 & 12.77 \\
1987 & 13.6 & 25.2 & 61.2 & 3.31 & 24.85 & 71.84 & 53.3 & 19.9 & 26.8 \\
1997 & 11.32 & 28.55 & 58.33 & 3.79 & 13.4 & 82.79 & 40.92 & 26.74 & 30.93 \\
2007 & 9.85 & 14.06 & 76.09 & 3.16 & 15.12 & 81.72 & 32.54 & 10.48 & 56.98 \\
\hline
\end{tabular}

Source: Bureau of Iranian Statistics 1967-2007

to 1997 . These Changes are directly related to an increase or decrease in people engaged in the service sector. The percentage of the population engaged in service sector compared to total labour force associated with Shiraz and Shiraz metropolitan along with its rural settlements shows a drastic increase at the end of this three consecutive decade (table 6). Shiraz metropolitan had multiple functions with high inclination and tendency toward agriculture in 1957. However, this city had multiple functions including commercial and services in 1967, 1977, 1987, 1997.

Shiraz itself possessed service function between 1957-07. However, its service role and function associated with 1957 was geared toward commercial function. The city entirely possessed service function toward the middle and the end of that period of time. That means the proportion and share of agricultural sector drastically declined. Rural areas of Shiraz metropolitan took agricultural role between1957-97. However, the city changed into multi-functions between 1397-07. Shiraz performed as a service nuclei in 2007 (figs 5, $6,7)$.

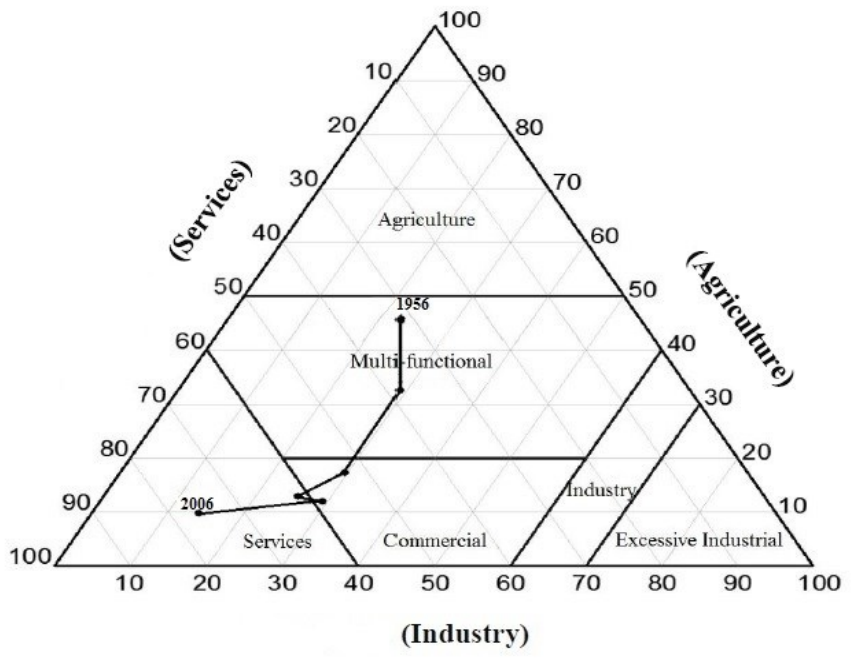

Figure 5. Predominant economic functions associated with Shiraz Metropolitan up to 2006

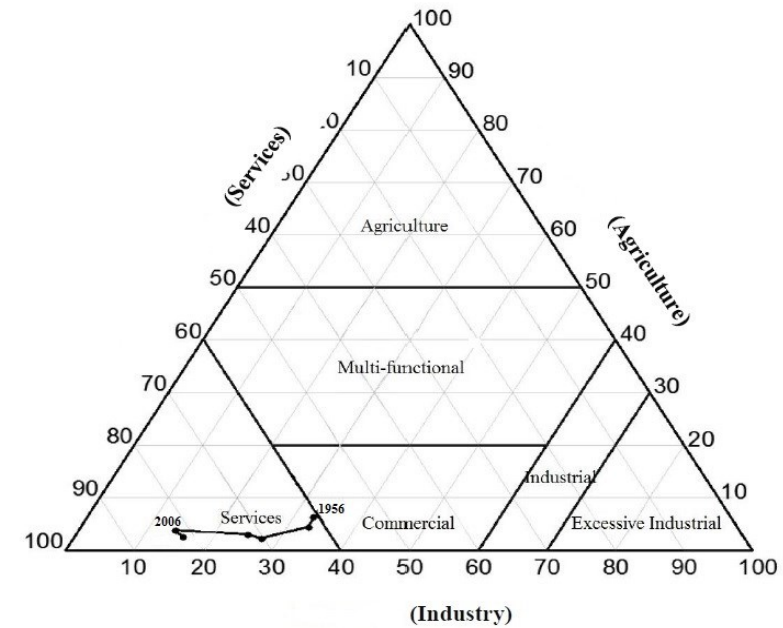

Figure 6. Predominant economic functions associated with Shiraz up to 2006

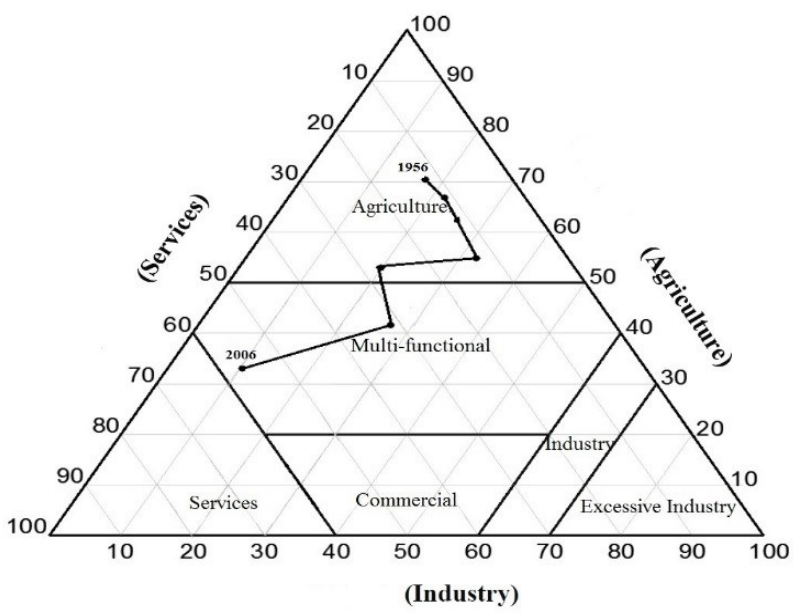

Figure 7. Predominant economic functions associated with Shiraz rural communities up to 2006

\section{Conclusion}

Aims of this paper was to identify, describe, and analyze Shiraz scatter and sprawl development and its resulting functional-structure over the period 1940-2016. The analysis of population growth and socioeconomic activities included 
Table 7. Correlation between degree of Shiraz scatter development and

Functional-structural changes associated with neighboring communities

\begin{tabular}{ccc}
\hline Variable & Correlation coefficient & Significant level \\
\hline Population growth rate & 0.127 & 0.8 \\
Urbanization coefficient & 0.726 & 0.1 \\
Number of people engaged in agriculture & -0.8 & 0.04 \\
Number of people engaged in industry & -0.811 & 0.09 \\
Number of people engaged in service & 0.9 & 0.001 \\
\hline
\end{tabular}

shifts in the different sectors and dominated theories of development made this paper successful to address the causes and effects these shift on spatial distribution of the main population patio-temporal dynamics of these rapid changes.

This study suggests that both Shiraz and Shiraz metropolitan experienced 3.41 percent and 4.03 percent population growth in 1957-07 respectively, which is higher than the associated figure for the Fars province (2.8). The population growth rate of both Shiraz metropolitan and Shiraz was increasing until 1987. However, following that year they experienced some population changes due to the population growth control policy as well as immigration associated with war migrants. It further argued that the Shiraz population growth rate compared with the corresponding figure for Shiraz metropolitan during 1997-07 was lower. This is associated with urban sprawl and scatter growth pattern over suburban areas.

Urbanization coefficient pertaining to Shiraz went up from 37.66 to 80.68 in 1997. However, this plummeted to 78 percent in 2007. The associated figures regarding Shiraz compared with Fars province and Shiraz metropolitan were much higher. Urban physical expansion associated with population growth plummeted from 77.98 percent to 27.2 in 1957-67, and 1997-07 respectively. However, sprawl and the scatter growth pattern increased from 22.02 to 72.8 respectively in the same time period. Population growth rate associated with Shiraz was 4.69 and 4.67 percent in 1957-67 and 1967-77 respectively. The area increased from 447 acres in 1957 to 894 in 1967 (1.8 fold) and 16.9 acres in 1977. Scatter and sprawl growth pattern followed both topographic configuration and major arteries direction. Shiraz Predominant physical expansion pattern followed continuous, linear, and scatter form in 1947-67, 1957-78 and 1987-07 respectively.

Shiraz scatters and sprawl development and expansion of neighboring areas from 1967-07 has led to new political, administrative subdivisions. Shiraz metropolitan possessed Multifunction with particular emphasis on agriculture in 1967. However, this type of function was geared toward commercial in 1967. This is followed by a mere service function. There was a very drastic decrease regarding agriculture sector. Shiraz rural settlements had agriculture function between1967-87. This is followed by possession of Multifunctions in 1997 and 2007.

Based on Pearson regression, correlation, there exists a significant relationship between the number of people engaged in the service sector, urbanization coefficient and population growth rate and degree of urban sprawl. It is argued that the higher the degree of urban sprawl, the higher would be the value of corresponding variables in Shiraz metropolitan (table 7).

However, there exists a negative relationship between the degree of urban sprawl and people engaged in industrial and agricultural sectors. This study further suggests that conversion of agricultural land use into residential and services resulted in a decrease in people engaged in the agricultural sector. It further suggests that the development of the service sector is associated with the slower growth of people engaged in the industrial sector.

\section{References}

Ahadnejad Reveshty, M., Tahmasebi moghaddam, H., Shami, F., Moharrami, S. (2019). Spatial explanation of urban sprawl phenomenon (Case study: Qaemshahr city). Journal of Urban Social Geography, 6(1), 1-13.

Barnes, H.B.; Morgan, J.M.; Roberge, M.C. \& Lowe, S. 2001. Sprawl Development: It's Patterns, Consequences, and Measurement, A white paper, Towson University. URL: http:// Chesapeake. Towson, Edu/landscape/urban sprawl/ own load/sprawl white_paper.pdf.

Bhatta, B. 2010. Analysis of Urban Growth and Sprawl from Remote Sensing Data, Springer-Verlag Berlin Heidelberg.

Bogart, T. W. 2006. Don't Call It Sprawl: Metropolitan Structure in the Twenty-First Century, York College of Pennsylvania Cambridge university press, Cambridge, New York, Melbourne, Madrid, Cape Town, Singapore, Sao Paulo Cambridge University Press, The Edinburgh Building, Cambridge cb2 2ru, UK, First published in print format.

Bruegmann, R. 2006. Sprawl: a compact history, The University of Chicago Press, Chicago 60637, Ltd., London.

Burchell, R.W.; Shad, N.A.; Lisotkin, D.; Phillips, H.; Downs, A.; Seskin, S. \& et al. 1998. The Costs of Sprawl Revisited, National Academy Press, Washington, DC.

Burchell, W. R.; Downs, A.; McCann, B. \& Mukherji, S. 2005. Sprawl Costs: Economic Impacts of Unchecked, Development, writing from the publisher: Island Press, 1718 Connecticut Ave., NW, Suite 300, Washington, DC 20009, Island Press is a trademark of The Center for Resource Economics.

Dilorenzo, W. 2000. The myth of suburban sprawl. USA Today, 128 (May), 54-56. Ding, C. (1998). The GIS-based humaninteractive TAZ design algorithm: examining the impacts of data aggregation on transportation-planning analysis, Environment and Planning B, 25.

Duany, A.; Plater-Zyberk, E. \& Speck, J. 2001. Suburban Nation: The Rise of Sprawl and the Decline of the American Dream, North Point Press, New York.

Ewing, R.; Pendall, R. \& Chen, D.D.T. 2002. Measuring Sprawl and Its Impact, Smart Growth America, Washington, DC. 
Fang, C., Chen, C., Zhao, M., \& LeGates, R. (2020). Integrating urban-rural development (IURD) through governance programmes in China's Megacities: The Suzhou model. In New Urban Agenda in Asia-Pacific (pp. 39-64). Springer, Singapore.

Feng, Y., \& Wang, X. (2020). Effects of urban sprawl on haze pollution in China based on dynamic spatial Durbin model during 2003-2016. Journal of Cleaner Production, 242, 118368 .

Frumkin, H.: Frank, L. \& Jackson, R. 2004. Urban Sprawl and Public Health: Designing, Planning, and Building for Healthy Communities, Island Press, and Washington, Covelo. London.

Galster, G.; Hanson, R.; Wolman, H.; Coleman, S. \& Freihage, J. 2001. Wrestling sprawl to the ground: defining and measuring an elusive concept, Housing Policy Debate, 12(4).

Giyarsih, S. R. (2017). Regional Management of Areas with Indications of Urban Sprawl in the Surrounding Areas of Universitas Muhammadiyah, Yogyakarta, Indonesia. Indonesian Journal of Geography, 49(1), 35-41.

Glaeser, E.L. \& Kahn, M.E. 2004. Sprawl and urban growth. In: V. Henderson and J. Thisse (eds.), the Handbook of Urban and Regional Economics, Oxford University Press, Oxford.

Gordon, P. \& Richardson, H.W. 1997. Are compact cities a desirable planning goal, Journal of the American Planning Association, 63(1).

Gutfreund, O.D. 2004. Twentieth Century Sprawl: Highways and the Reshaping of the American Landscape, published by Oxford University Press, Inc.198 Madison Avenue, New York, New York 10016, www.oup.com.

Harvey, D. 1996. Social Justice and the City. Translated by Farrokh Hesamian et.all. First edition, Urban Analysis and Planning Institute. Tehran, Iran.

Herold, M.; Hemphill, J.; Dietzel, C. \& Clarke, K.C. 2005. Remote Sensing Derivved Mapping To Support Urban Growth Theory, ESA GOFC-GOLD Land Cover Project Office, Dep. of Geography, FSU Jena, Loebedergraben 32, 07743 Jena, Germany-m.h@uni-jena.de. Dep. of Geography, University of California Santa Barbara, Ellison Hall, Santa Barbara, CA, 93106, USA - (jeff, dietzel, kclarke) @geog.ucsb.edu. http:// www.isprs.org/proceedings/XXXVI/8-W27/ herold_hemphill_etal.pdf.

Hess, G. R. 2001. Just what is sprawl, anyway? www4.ncsu.edu/ grhess.

Hussain, M., Chen, D., Cheng, A., Wei, H., \& Stanley, D. (2013). Change detection from remotely sensed images: From pixelbased to object-based approaches. ISPRS Journal of photogrammetry and remote sensing, 80, 91-106.

Hydari, J.; Soleimani, M .2013. Infill Development with Emphasis on Texture Decay Renewal. First published. Azarakhsh Publision. Tehran, Iran.

Johnson, M.P. 2001. Environmental impacts of urban sprawl: a survey of the literature and proposed research agenda, Environment and Planning A, 33.

Kamanroodi, M. 2006. Tehran's land uses Spatial Analysis with Emphasis upon Municipalities role during 1991-2002, Ph.D Dissertation Shahid Beheshti University.

Kamanroodi, M. 2014. First edition of Environmental Hazard, Excellences of Spatial Environmental Hazard, Jahad Publication Khurazmi University, Tehran. Iran.

Kiggundu, A. T. (2014). Constraints to urban planning and management of secondary towns in Uganda. Indonesian Journal of Geography, 46(1), 12-21.

Komarovskiy, V. and Bondaruk, V. 2013. The role of the concept of "growth poles" for regional development. Journal of Public Administration, Finance and Law. Issue 4/2013

Kovács, Z., Farkas, Z. J., Egedy, T., Kondor, A. C., Szabó, B., Lennert, J., ... \& Kohán, B. (2019). Urban sprawl and land conversion in post-socialist cities: The case of metropolitan Budapest. Cities, 92, 71-81.
Mendonça, R., Roebeling, P., Martins, F., Fidélis, T., Teotónio, C., Alves, H., \& Rocha, J. (2020). Assessing economic instruments to steer urban residential sprawl, using a hedonic pricing simulation modelling approach. Land Use Policy, 92, 104458.

Meshkini, A. \& Parhiz, F. 2011. Urban Sprawl Pattern, Typology, dimensions, and Influential variables. Armanshahr Magazine, Issue no 5, 169-184.

Movahed, A., \& Jafarpour Ghalehteimouri, K. (2019). The importance of the concept and meaning of place in tourism geography. Journal of Tourism, Hospitality and Environment Management, 4(16), 01-09.

Nedaetousi, S., \& Bagheri, B. (2017). Defining the sprawl phenomenon in Metropolitan areas case study: Shiraz Metropolitan Area. Journal: Geography And Development Summer 2017, Volume 15, Number 47; Page(s) 185 To 211.

Nengroo, Z. A., Bhat, M. S., \& Kuchay, N. A. (2017). Measuring urban sprawl of Srinagar city, Jammu and Kashmir, India. Journal of Urban Management, 6(2), 45-55.

Ottensmann, J.R. 1977. Urban sprawl, land values and the density of development. Land Economics, 53(4).

Paydar, M., \& Rahimi, E. (2018). Determination of urban sprawl's indicators toward sustainable urban development. Smart and Sustainable Built Environment.

Peiser, R. 2006. Decomposing urban sprawl, Town Planning Review, $72(3)$.

Rahman, G.; Alam, D. \& Islam, S. 2008. City growth with urban sprawl and problems of management, Proceedings of 44th ISOCARP Congress Dalian, China, September 19-23, International Society of City and Regional Planners and Urban Planning Society of China.42-RERC (Real Estate Research Corporation) (1974). The costs of sprawl: Environmental and economic costs of alternative residential patterns at the Urban Fringe, US Government Printing Office, Washington, DC.

Rostow, W.W. 1955. The Economic History Review. Published by: Wiley on behalf of the Economic History Society. Vol. 12, No. 1, 1959

Rush, M. 1999. Society and Policy: Introduction on Political Sociology. Translated by Saburi, M. First Published. SAMT publisher. Tehran, Iran.

Saeedi, A .2013. Functional Structural Dynamic, An Alternative Approach in Spatial Planning, Space Economy and Rural Development Periodical, First Issue.Kharazmi University, Tehran, Iran. 1-18.

Saeedi, A. \& Shafie, S.N. 2011. Landscape corrosion and Changes of Agriculture Land Use. Case Tehrans' Metropolitan neighboring Communities in Saeedi .Abass 2011, Iran's urban rural Linkages, Minou Publication. Tehran, Iran.

Soleimani M, Afrakhteh H, Saeednia A, Chegini R. The Analysis of Spatial-Physical Consequences of the Rural Centers Integration in Region One of Tehran. ) 2013 (قتصاد فضا. 2 (a) .149-115: (3Economy of Space and rural Development 3. Kharazmi University. Tehran, Iran. 115-149.

Stlawa. I. 2000. Time space compression. http://it.stlawa.edu.

Weitz, J. and Moore, T. 1998. Development inside urban growth boundaries: Oregon's empirical evidence of contiguous urban form, Journal of the American Planning Association, 64(4).

Williamson, T. 2010. Sprawl, Justice, and Citizenship: The Civic Costs of the AmericanWay of Life, Published by Oxford University Press, Inc.198 Madison Avenue, New York, New York 10016, and www.oup.com.

Zhang, B. 2004. Study on Urban Growth Management in China, Xinhua Press, Beijing.

Zhao, S. X., Wong, D. W., Wong, D. W., \& Jiang, Y. P. (2020). Evertransient FDI and ever-polarizing regional development: Revisiting conventional theories of regional development in the context of China, Southeast and South Asia. Growth and Change, 51(1), 338-361. 